\title{
Debunking the one-size-fits-all approach to human resource management: A review of human resource practices in small and medium-sized enterprise firms
}

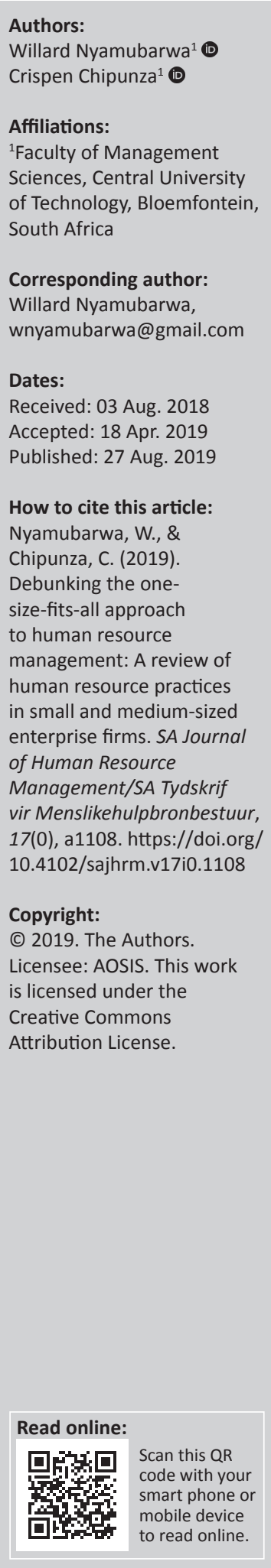

Orientation: This article argues that the best practice approach (BPA) to HRM fails to capture the peculiarities of HR practices in small and medium-sized enterprises (SMEs). The article instead articulates the view that the different and unique traits inherent in SMEs firms allows the firms to adopt distinct HR practices, which may not cohere with the prescriptive one-size-fits-all view which BPA advocates.

Research purpose: The article aims to further the thesis that the long-held BPA approach to HRM does not always apply to SME firms given their unique characteristics which renders HR prescriptions applied in large firms invalid in SME firms.

Research approach/design and method: As a theoretical article, a systematic literature review was conducted to draw findings and conclusions.

Main findings: The article concludes that the eclectic nature of SME HR practices complicates the extent of generalisability of such practices across organisational settings, thus showing that HR practices that work in SME firms cannot be applied in large firms with equal success.

Practical/managerial implications: The findings provide a platform to enhance the understanding surrounding managing human resources in SME firms by revealing the differences between people management in SME firms as compared to their larger counterparts.

Contribution/value-add: The article is groundbreaking as it has opened new avenues in the quest to understand the nature and contribution of HRM in SME firms.

Keywords: best practice approach; human resource management; small and medium-sized enterprises; recruitment; training; performance management; rewards management.

\section{Introduction}

There is no universally accepted definition of what constitutes a small business, and as a result, as Berisha and Pula (2015) report, what may be regarded in one country as a small business, would often be regarded as a medium-sized or even as a large enterprise elsewhere in the world. In South Africa, the National Small Business Act of 2004 categorises small businesses into the following distinct groups: Micro, very small, small and medium enterprises with the category size based on the financial performance as well as the number of employees in each enterprise. In light of this, this article's definition of an SME firm considers all categories of SME firms as stipulated in the Small Business Act of 2004 ranging from Micro enterprises with a turnover that is less than the annual value-added tax (VAT) registration limit and employing less than 10 employees, to medium-sized enterprises which employ up to 200 employees.

Meanwhile, according to Psychogios, Szamosi, Prouska and Brewster (2016), people management issues in SME firms are associated with informality, instability, authoritarianism and conflict. This article seeks to contest this widely held notion that SMEs' HR practices are minimalist in nature and therefore cast doubt on the applicability to large enterprises. These negative connotations are best explored in a study by Harney and Nolan (2014) who concluded that as most SMEs cannot afford to have professional HR departments, their HR practices are poor and characterised by inadequate health and safety systems and low-trade union activity, creating frictional conflict leading to higher absenteeism and high turnover. To further compound this challenge, the mainstream literature suggests that HR practices in SME firms are derived from large enterprises and are unreflectively imposed on SMEs without regard to their unique set up (Saridakis, Muñoz-Torres, \& Johnstone, 2013; Sheehan, 2014). As a result, there is a growing consensus that 
the mainstream HR literature ignores the peculiarities of SMEs such as their limited budgets; dominance by the owner-manager and their agility in the face of uncertainty, which lend themselves to adopt distinct HR practices that may not cohere with the prescriptive one-size-fits-all view, which BPA advocates (Wiesner \& Innes, 2010). Therefore, these unique characteristics of SME firms have led to the manifestation of HR in SMEs in two divergent perspectives: the 'small is beautiful' and the 'bleak house' perspectives. The 'bleak house' model views people management in SMEs as characterised by employee exploitation, low wages and long working hours. On the other hand, the 'small is beautiful' approach views HR in SMEs as characterised by decent wages, pleasant working conditions and a healthy mutually beneficial relationship between the employees and the SME owner-manager (Richbell, Szerb, \& Vitai, 2010; Wilkinson, 1999; Woodhams \& Lupton, 2006).

\section{Problem statement}

This article argues that most HR literature view SMEs as scaled-down versions of big enterprises, notwithstanding the uniqueness of such firms as reflected by their small size and their resource limitations (Dundon \& Wilkinson, 2009). As such, the most common theme running across this literature, which takes motivation from the BPA, is that, HR practices that are tried and tested in big companies may also be applied and used in small firms with equal success (Psychogios et al., 2016; Tsai, 2010). This reasoning is derived from the seminal paper by Welsh and White (1981) who claim that SMEs are essentially the same as large firms but on a smaller scale and therefore what is ideal for large firms applies in equal measure to SME firms. The problem with this minimalist and reductionist perspective to the practice of human resource management (HRM) is that it ignores the unique set of environmental circumstances inherent in SME firms that make HR practices therein unique and different from what prevails in large firms.

Therefore, this article seeks to explore the veracity of the BPA-inspired view that a prescribed set of HR practices can be applied generically to all organisations big or small with the same result or may be, as Sheehan (2014) notes there is a distinctive difference in approach to people management between small and large firms, and these different approaches are beneficial to either size of enterprise.

\section{Theoretical underpinnings}

According to Cunningham (2010), there are glaring differences of opinion on what constitutes HRM in SME firms. On the one hand, Wilkinson (1999) describes people management methods in SMEs as 'harmonious' as compared to those in larger firms granted that the small size of SME firms creates a family-like environment that spawns good working conditions such as open communication channels, flexibility of work practices and low levels of conflict. On the other hand, some scholars (Bacon, Ackers, Storey, \& Coates, 1996; Sisson, 1993) claim HR management in SME firms represents a 'bleak house' scenario where the small firm setting is fertile ground for informality, instability, authoritarianism and conflict. This 'bleak house' phenomenon is unpacked by Psychogios et al. (2016) who reaffirm that this indicates that HR practices in SME firms are unique given the fact that most SMEs do not have professional HR departments, and as a result, their HR practices are best described as informal and reactive and are associated with poor working conditions. This article therefore seeks to lay bare literature that explores this minimalist and reductionist perspective to the practice of HRM in SMEs, which follow the BPA-driven approach that HR practices can be applied generically to all organisations big or small with the same successful results.

\section{Methodology}

This article is attempting to explore the validity of the perception that, HR practices are generic and therefore can be applied with success in any organisation, of any shape and size. In the interest of striking a balance between the most recent literature trends and the need for an in-depth analysis, a systematic search of literature was conducted and the identified studies were matched against a number of criteria. Firstly on peer-reviewed journals the literature search was conducted on the following academic databases Academic Search Premier, ERIC, Business Source Elite and Business Source Premier using the key terms 'HR practices in SME firms'. As recommended by Bergh (2012) this article used Boolean logic to refine the literature searches to the range of 100-150 hits per keyword search. This had the effect of focusing the literature searches on the core thesis proposed in this article. In addition, selective searches were carried out on Google Scholar using the same search terminology to widen the literature reach.

\section{Ethical considerations}

Ethical clearance to conduct this study was obtained from the Faculty of Management Sciences of the Central University of Technology, Free State (reference 090214).

\section{Data analysis}

Given the qualitative approach adopted to produce this article, a thematic analysis was applied to produce meanings and draw conclusions in this article. According to Braun and Clarke (2006) thematic analysis involves the repeated reading and analysing of texts and the identification of key themes and concepts drawn from across diverse literature claims. Likewise, this article used thematic analysis to isolate literature that reveals that HR practices in SME firms are unique and appropriate for their size and resource constraints.

\section{Observations and reflections}

As previously reported, the practice of HR in SME firms is unique as compared to what prevails in big enterprises. This uniqueness stems from the SME firm's dependence on the owner-manager's management styles, the small size of the firm and its flexibility in the face of the uncertainty of the operating environment. Fabi, Raymond and Lacoursière (2009) 
concur and report that this uncertainty often leads to informality in the practice of HR given the fact that the owner-manager who at most times is not an HR expert would not be in a position to manage the effect of such uncertainties in the management of human resources stemming from the operating environment.

In fact, as Cameron and Miller (2008) explain, SME firms prefer the independence and flexibility associated with operating informally, forcing them to disregard the prescriptive one-size-fits-all view, which BPA advocates. The argument is therefore made that an informal approach to people management is more suited to small firms because it is associated with flexibility, in which flexibility assists them in coping with the operational uncertainty that characterises their operating environment (Matejun, 2014).

Meanwhile, according to Pittino, Visintin, Lenger and Sternad (2016) given the small size of SME firms, their employees enjoy a feeling of proximity to the owner-managers which creates feelings of commitment, loyalty and generally good working conditions in SME firms (Wiesner \& Innes, 2010). Thus, in this case, the SME owner-manager assumes a paternalistic role and strives to keep every employee happy through the application of HR practices that appeal to the interest of every employee in the firm (Pittino et al., 2016). This is different from what prevails in larger firms where the practice of HR is impersonal and sometimes impersonal and autocratic as it is a product of, and driven by, formal policies and procedures (Harney \& Dundon, 2006). This indicates that the unique traits of SMEs lend themselves to adopt distinct HR practices which may not cohere with the prescriptive one-size-fits-all view which BPA advocates.

Additionally, the SME owner-manager occupies a strong decision-making position in firms, and as a result, the ownermanagers exert considerable personal influence on business practices including the practice of HR (Lobonțiua \& Lobonțiua, 2014). As a result, many SME firms prefer not to have professionally run HR departments, and major HR decisions are usually made solely by the owner-manager who may not be an HR expert in the first place (Fabi et al., 2009; Kotey \& Slade, 2005; Rauf, 2016). Even in the rare cases where HR professionals are employed, it is still the ownermanager who naturally assumes responsibility over people management and other key business activities in the firm (Kroon, Voorde, \& Timmers, 2013). Although this arrangement contrasts with people management in large organisations where professional HR managers are employed to provide guidance in HR issues (Wiesner \& Innes, 2010), this article surmises that it does not follow that there is anything wrong with HR management in SME firms but rather shows that HR practices in SMEs are unique and suited to the structural and environmental circumstances of SME firms.

\section{Recruitment practices in the small and medium-sized enterprise firm}

Methods used to recruit employees in SME firms are unique and at variance with methods used in larger firms
(Cameron \& Miller, 2008). As Bacon and Hoque (2005) reaffirm, SMEs tend to recruit most of their employees from among their close kinship ties and not from the open labour market like large firms. This requires only a few and unsophisticated HRM competencies thus rendering the whole recruitment exercise ad hoc and informal. This is in contrast to the situation in larger enterprises that are forced to adopt standardised recruitment practices that allow the firm to operate flexibly on the recruitment market (Young-Thelin, \& Black, 2012). All of these, as Bacon and Hoque (2005) note, place high value on the recruited employees, which in turn leads to a sustained competitive advantage for the firm as proposed by Barney (1991) in his resource-based view approach to the management of employees in organisations.

From the foregoing analysis, the authors conclude that SME firms face a number of challenges when recruiting capable employees, because they apply what may appear to be less appealing, hiring channels such as social networks and walkins in contrast to the more robust recruitment methods used by large enterprises. However, as literature has revealed, recruitment practices used by SMEs augur well with these resource-constrained firms owing to the fact that such recruitment practices are cheap and therefore best suited to SME firms that at most face resource limitations. In other words, this supports the proposition that HR practices cannot be generically applied to all organisations big or small with the same result.

\section{Training in the small and medium-sized enterprise firm}

In the discipline of HRM, training is viewed as an essential contributor to the improvement of employee competence (Armstrong, 2013). Thus, training in HR is viewed as an exercise that should be done sorely to improve the individual employee's ability to contribute better towards the achievement of the firm's objectives. This is not the case in SME firms where, as Leach (2011) notes, employees are trained according to what best suits their personal interests which at most times is not in tandem with the firm's objectives. As a result, as Young-Thelin and Black (2012) note, like all HR functions, formal training is less likely to be provided in SMEs as many owner-managers view training in SMEs as inefficient and not contributing to firm objectives. Where training is given, the training is mostly informal, short-term and in-house with little or no provision for management development (Kotey \& Slade, 2005).

According to Guercin and Milanesi (2016) this clearly shows the fault lines in SME training practices confirming that HRM in SME firms represents a minimalist and reductionist perspective to the practice of HRM as compared to large firms. Kotey and Folker (2007) take an alternative viewpoint and argue that such training is most appropriate in SMEs as it is geared towards meeting the business needs of SME firms, which tend to vary from time to time. In light of this view, this article concludes that this state of affairs indicates 
that even though training in SME firms is informal and ad hoc, this is in sync with basic training needs of most SME firms, thus showing that HR practices in SME firms should not carry stereotypes of depravity derived from the BPA approach. They should be viewed as a different and unique approach-to-strategy, which is useful in SME firms.

\section{Performance management in the small and medium-sized enterprise firm}

According to Forth and Bryson (2018), performance management is a continuous process of aligning the goals of employees with those of the organisation they work for. What this implies is that performance management entails regular evaluation of employee performance to ensure that at all times, employees will contribute to the organisation's objectives (Ogunyomi \& Bruning, 2016). In other words, performance management is the process of designing and executing HR interventions that can aid in the enhancement of employee performance (Yusoff, Razak, Zainol, \& Hassan, 2018).

Meanwhile, SME firms, like any other form of business enterprise, also need to constantly conduct performance appraisal to constantly realign employee performance with firm interests (Cunningham, 2010). However, a perusal of the performance appraisal methods used in SME firms shows that they are significantly different from those used in large firms, thus showing that HR practices in SME firms are radically different from those in large firms.

According to Steijvers, Lybaert and Dekker (2012), given the fact that HR in SME firms is the responsibility of the ownermanager who may not possess any HR expertise, many such owner-managers perceive formal performance appraisal system as time consuming and complex. Therefore, the most common appraisal methods within SMEs are narrative descriptions of employee performance and the use of rating scales (Ahmad \& Alaskari, 2014). This scenario is explained by the fact that by working alongside employees, SME owner-managers can directly observe employee activities and take corrective measures almost immediately, therefore indicating that performance management in SME firms is mainly informal and a continuous process (Ahmad \& Alaskari, 2014; Kotey \& Folker, 2007). This informality should not indicate any negativity often associated with the practice of HR in SME firms but should instead be viewed as lending credence to the proposition that HR practices cannot be generically applied to all organisations big or small with the same result.

\section{Rewards management in the small and medium-sized enterprise firm}

According to Michiels, Voordeckers, Lybaert and Steijvers (2012), SME firms are less likely to be perceived as the firstchoice employers by potential employees in the labour market. This is given the fact that SME firms suffer from resource limitations (Dundon \& Wilkinson, 2018)), and as a result, this hinders their ability to offer attractive reward packages required to retain highly talented employees (Long, Ajagbe, \& Kowang, 2013). SME firms counterbalance this by taking advantage of reward savings stemming from agency relationships. Michiels et al. (2012) explain that the small family-like environment in SME firms engenders a feeling of kinship, altruism and loyalty between the owner-manager and the rest of the employees. This familial environment aligns the interest of the owner-manager with that of the rest of the employees thus eradicating any need for agency payments. This implies that any agency cost that a normal firm would encounter to align managerial interests to those of the rest of the employees will be done away with, given that any possible acts of self-interest will be tempered by the lure of kinship, altruism and loyalty (Michiels et al., 2012). This line of thinking leaves the author to conclude that unlike the widely held BPA prescriptions, the reward management systems in SME firms are most appropriate given their size, resource constraints and environmental influence.

\section{Evaluation of contribution}

This theoretical article is an attempt to draw the line between HR practices in SME firms and those prevailing in larger businesses. The article does this by exploring the veracity of the BPA-based perception that a prescribed set of HR practices can be applied generically to all organisations big or small with the same result. In other words, there is a distinctive difference in approach to people management between small and large firms, and these different approaches are beneficial to either size of enterprises. The article therefore makes a significant contribution to the field of HRM in SMEs by revealing how the unique nature of people management practices in small firms debunks the commonly held perception that HR practices in small firms are inferior to those used in large organisations.

Firstly, the findings of the article show that HR practices in SME firms are at best described as a spectrum of stereotypes. This is drawn from the observations that HRs in SMEs are widely viewed as informal, emergent and reactive, partly because of the owner-manager's sole role in making HR decisions and partly from the idiosyncrasies associated with SME firms (Singh \& Vohra, 2009). This explains the unique nature of HR practices that characterise firms that are glaringly absent in larger firms. On the basis of these arguments, one may conclude that HR practices in SME firms can also be described as stereotypically characterised with unique, eclectic and appropriate for SME firms.

Secondly, research focusing on understanding the nature HR practices in SMEs has been generally passive, partly because of the BPA-driven belief that HR practices can be universally applied to all kind of firms with equal success (Tsai, Sengupta, \& Edwards, 2007). This article casts aspersions to this view and seeks to assert that, on the contrary, HR practices that work in SME firms are different from and may not work in larger enterprises. This may be linked to the claims by Cunningham (2010) who presented the thesis claim that, SME 
firms are not a 'scaled-down' version of large firms, and as such, the unique structure as determined by its small size and resource limitations is revealed in the nature of its HR practices, which are significantly different from those of large firms.

Finally, the article provides a basis for testing theories that are commonly applied to explain HR management in both large and small organisations. The article therefore explores the applicability of the Agency Theory and the Resourcebased View theory by explaining HR practices in SME firms. The findings help us to reconcile the previous conflicting arguments about the applicability of these theories to explain HR practices in SME firms.

\section{Conclusion}

From the foregoing, this article has shown that SME firms often have a unique approach to the practice of HRM which captures the peculiarities of SME firms (Birdthistle, 2006; Reid \& Adams, 2001). As such, HR practices in SMEs tend to be informal and reactive to the needs of the firm. This article concludes that this state of affairs does not reflect anything wrong with the practice of HR in SME firms but rather explains the unique nature of $\mathrm{HR}$ practices that characterise SME firms, which are glaringly absent in larger firms.

\section{Recommendations}

Given the theoretical nature of this study, it follows that this article is based on the reasoning and perceptions by different scholars and not on empirical research. This same theoretical view can be challenged on an equal footing by drawing on alternative existing literature to make new theoretical propositions that prove that HR practices in SME firms are similar to those in large enterprises. As a result, it is recommended that future researchers take it from here and conduct empirical research to validate the finding of this article.

\section{Implications for future research}

Future researchers are challenged to tunnel deeper and question the nature of the HR management practised in SME firms. Indeed, research should be carried out that will further entrench the view that HR practices in SME firms are unique and most appropriate for the structural environment characterising SME firms.

\section{Acknowledgements Competing interests}

The authors declare that they have no financial or personal relationships that may have inappropriately influenced them in writing this article.

\section{Authors' contributions}

This article is derived from the PhD thesis of W.N. entitled 'Development and testing of a framework for the formalisation of HR practices among small family-owned accommodation firms in South Africa'. C.C. was the PhD supervisor and was responsible for methodology, data analysis and editing of this article.

\section{Funding information}

The authors acknowledge that funding for the production of this article was kindly made available by the Central University of Technology, Free State.

\section{Data availability statement}

Data sharing is not applicable to this article as no new data were created or analysed in this study.

\section{Disclaimer}

The views and opinions expressed in this article are those of the authors and do not necessarily reflect the official policy or position of any affiliated agency of the authors.

\section{References}

Ahmad, M. M., \& Alaskari, O. (2014). Development of assessment methodology for improving performance in SME's. Performance Management, 63(4), 477-498. https://doi.org/10.1108/IJPPM-06-2013-0108

Armstrong, M. (2013). Armstrong's handbook of human resource management practice (13th ed.). London: Kogan Page.

Bacon, N., Ackers, P., Storey, J., \& Coates, D. (1996). It's a small world: Managing human resources in small businesses. The International Journal of Human Resource Management, 7(1), 82-100. https://doi.org/10.1080/09585199600000119

Bacon, N., \& Hoque, K. (2005). HRM in the SME sector: Valuable employees and coercive networks. The International Journal of Human Resource Management, 16(11), 1976-1999. https://doi.org/10.1080/09585190500314706

Barney, J. (1991). Firm resources and sustained competitive advantage. Journal of Management, 17(1), 99-120. https://doi.org/10.1177/014920639101700108

Bergh, G. (2012). Systematic review in international development. London: Internal.

Berisha, G., \& Pula, J. S. (2015). Defining small and medium enterprises: A critical review. Academic Journal of Business, Administration, Law and Social Sciences, 1(1), 17-28

Birdthistle, N. (2006). Small family businesses as learning organisations: An Irish study. PhD thesis. Brisbane: Griffith University.

Braun, V., \& Clarke, V. (2006). Using thematic analysis in psychology. Qualitative Research in Psychology, 3(2), 77-101.

Cameron, L., \& Miller, P. (2008). Enhancing HR practices in SMEs using the concept of relationship marketing. In Proceedings of the SME entrepreneurship global conference 2008: Creating sustainable entrepreneurship eco-system and highperformance SMEs (pp. 1-16). Melbourne, Australia.

Cunningham, L. X. (2010). Managing human resources in SMEs in a transition economy: Evidence from China (PhD Thesis). The International Journal of Human Resource Management, 21(12), 2120-2141. https://doi.org/10.1080/09585192.2 010.509620

Dekker, J., Lybaert, N., Steijvers, T., \& Depaire, A. B. (2015). The effect of family business professionalization as a multidimensional construct on firm performance. Journal of Small Business Management, 53(2), 516-538. https://doi.org/10.1111/ jsbm.12082

Dundon, T., \& Wilkinson, A. (2009). HRM in small and medium sized enterprises (SMEs). In G. Wood, Human resource management. A critical approach (pp. 130-147). London: Routledge.

Dundon, T., \& Wilkinson, A. (2018). HRM in small and medium-sized enterprises (SMEs). In G. Wood, \& Collings, D. G. (Eds.), Human resource management: $A$ critical introduction (pp. 1-32). London: Routledge.

Fabi, B., Raymond, L., \& Lacoursière, R. (2009). Strategic alignment of HRM practices in manufacturing SMEs: A Gestalts perspective. Journal of Small Business and Enterprise Development, 16(1), 7-25. https://doi.org/10.1108/146260009 10932854

Forth, J., \& Bryson, A. (2018). The impact of management practices on SME performance. Bonn, Germany: IZA Institute of Labour Economics.

Guercin, S., \& Milanesi, M. (2016). Interaction approach and liabilities: A case analysis of start-up firms. Journal of Business-to-Business Marketing, 23(4), 293-309. https://doi.org/10.1080/1051712X.2016.1250595

Harney, B., \& Dundon, T. (2006). Capturing complexity: Developing an integrated approach to analysing HRM in SMEs. Human Resource Management Journal, 16(1), 48-73. https://doi.org/10.1111/j.1748-8583.2006.00004.x 
Harney, B., \& Nolan, C. (2014). HRM in small and medium-sized firms (SMEs). In B. Harney, Strategic HRM: Research and practice in Ireland (pp. 153-169). Dublin: Harney, Strategic
Blackhall/Orpen.

Kotey, B., \& Folker, C. (2007). Employee training in SMEs: Effect of size and firm type - Family and non-family. Journal of Small Business Management, 45, 214-238. https://doi.org/10.1111/j.1540-627X.2007.00210.x

Kotey, B., \& Slade, P. (2005). Formal human resource management practices in small growing firms. Journal of Small Business Management, 43(1), 16-40. https://doi. org/10.1111/j.1540-627X.2004.00123.x

Kroon, B., Voorde, K., \& Timmers, J. (2013). High performance work practices in small firms: A resource-poverty and strategic decision-making perspective. Small Business Economics, 41(1), 71-91. http://doi.org/10.1177/0266242616 637415

Leach, P. (2011). Family businesses: The essentials. London: Profile Books.

Lobonțiua, G., \& Lobonțiua, M. (2014). The owner-manager and the functional management of the small firm. Procedia - Social and Behavioral Sciences, 124, 552-561. https://doi.org/10.1016/j.sbspro.2014.02.519

Long, C. S., Ajagbe, M. A., \& Kowang, T. O. (2014). Addressing the issues on employees' turnover intention in the perspective of HRM practices in SME. Procedia - Socia and Behavioral Sciences, 129, 99-104. https://doi.org/10.1016/j.sbspro.2014. 03.653

Matejun, M. (2014). The role of flexibility in building the competitiveness of small and medium enterprises. Management, 18(1), 152-168. https://doi.org/10.2478/ manment-2014-0012

Michiels, A., Voordeckers, W., Lybaert, N., \& Steijvers, T. (2012). CEO compensation in private family firms: Pay-for-performance and the moderating role of ownership and management. Family Business Review, 26(2), 140-160. https://doi.org/ 10.1177/0894486512454731

Ogunyomi, P., \& Bruning, N. (2016). Human resource management and organisational performance of small and medium enterprises (SMEs) in Nigeria. The International Journal of Human Resource Management, 27(6), 612-634. https://doi.org/10.108 $0 / 09585192.2015 .1033640$

Pittino, D., Visintin, F., Lenger, T., \& Sternad, D. (2016). Are high performance work practices really necessary in family SMEs? An analysis of the impact on employee retention. Journal of Family Business Strategy, 7(2), 75-89. https://doi.org/ 10.1016/j.jfbs.2016.04.002

Psychogios, A., Szamosi, L., Prouska, R., \& Brewster, C. (2016). A three-fold framework for understanding HRM practices in South-Eastern European SMEs. Employee Relations, 38(3), 1-38. https://doi.org/10.1108/ER-07-2014-0078

Rauf, M. A. (2016). HRM effectivity in small and medium-sized enterprises: A multiple cross-case study of Pakistani and Dutch SMEs. PhD thesis. University of Twente.
Reid, R. S., \& Adams, J. S. (2001). Human resource management - A survey of practices within family and non-family firms. Journal of European Industrial Training, 25(6), 310-320.

Richbell, S., Szerb, L., \& Vitai, Z. (2010). HRM in the Hungarian SME sector. Employee Relations, 32(3), 262-280. https://doi.org/10.1108/01425451011038799

Saridakis, G., Muñoz-Torres, R., \& Johnstone, S. (2013). Do human resource practices enhance organisational commitment in SMEs with low employee satisfaction? British Journal of Management, 24(3), 445-458. https://doi.org/10.1111/j.14678551.2012.00814.x

Sheehan, M. (2014). Human resource management and performance: Evidence from small and medium-sized firms. International Small Business Journal, 32(5), 545-570. https://doi.org/10.1177/0266242612465454

Singh, M., \& Vohra, N. (2009). Level of formalisation of human resource management in small and medium enterprises in India. Journal of Entrepreneurship, 18(1), 95-116.

Sisson, K. (1993). In search of HRM. British Journal of Industrial Relations, 31(2) 201-210. https://doi.org/10.1111/j.1467-8543.1993.tb00389.x

Steijvers, T., Lybaert, N., \& Dekker, J. (2012). Formal human resource practices in family firms. Journal of Family Business Management, 7(2), 151-165. https://doi. org/10.1108/JFBM-07-2016-0016

Tsai, C., Sengupta, S., \& Edwards, P. (2007). When and why is small beautiful? Human Relations, 60, 1779-1808.

Tsai, C.-J. (2010). HRM in SMEs: Homogeneity or heterogeneity? A study of Taiwanese high-tech firms. The International Journal of Human Resource Management, 21(10), 1689-1711. https://doi.org/10.1080/09585192.2010.500490

Welsh, J. A., \& White, J. F. (1981). A small business is not a little big business. Harvard Business Review, 59(4), 18. https://doi.org/10.1177/026624268200100115

Wiesner, R., \& Innes, P. (2010). Bleak house or bright prospect? HRM in Australian SMEs over 1998-2008. Asia Pacific Journal of Human Resources, 48(2), 151-184. https://doi.org/10.1177/1038411110368465

Wilkinson, A. (1999). Employment relations in SMEs. Employee Relations, 21(3), 206-217. https://doi.org/10.1108/01425459910273062

Woodhams, C., \& Lupton, B. (2006). Does size matter? Gender-based equal opportunity in UK small and medium enterprises. Women in Management Review, 21(2), 143-169. https://doi.org/10.1108/09649420610650710

Young-Thelin, L., \& Black, K. (2012). A case study of human resource practices in small hotels in Sweden. Journal of Human Resources in Hospitality \& Tourism, 11(4), 327-353. https://doi.org/10.1080/15332845.2012.690683

Yusoff, M. N., Razak, R. C., Zainol, F. A., \& Hassan, H. (2018). Entrepreneurial orientation and usage of external business support for SMEs. International Journal of Academic Research in Business and Social Sciences, 8(1), 1-11. 